\title{
SERTIFIKASI PRODUK (SNI) ALAT KESEHATAN DAN ALAT KESEHATAN DIAGNOSTIK IN VITRO SECARA WAJIB
}

\section{Product Certification (SNI) for Medical Devices and In Vitro Diagnostic Medical Devices by Mandatory}

\author{
Beluh Mabasa Ginting \\ Purnabakti Direktorat Pengawasan Alat Kesehatan \& PKRT Kementerian Kesehatan RI \\ Jl. Rasuna Said Jakarta Selatan. \\ Email : beluhmabasa13@gmail.com
}

\begin{abstract}
Abstrak
Jumlah produsen alat kesehatan dan alat kesehatan Diagnostik In Vitro yang telah memiliki sertifikat SNI saat ini sangat terbatas. Tujuan paper ini untuk menggambarkan bahwa Sertifikasi Produk (SNI) Alat Kesehatan dan Alat Kesehatan Diagnostik In Vitro secara wajib sangat dibutuhkan karena sertifikat SNI sebagai bukti bahwa alat kesehatan tersebut telah memenuhi standar sesuai dengan standar yang diklaim oleh produsen khususnya yang terkait dengan keselamatan dan kinerja (safety dan performance) berdasarkan hasil uji laboragtorium yang terakreditasi seperti yang diamanatkan oleh Undang-Undang No.36 Tahun 2009 Tentang Kesehatan dan Undang-Undang No.20 Tahun 2014 Tentang Standardisasi dan Penilaian Kesesuaian sehingga meningkatkan kepercayaan pasar baik di dalam negeri maupun pasar global. Sertifikat Produk (SNI) Alat Kesehatan dan Alat Kesehatan Diagnostik In Vitro diharapkan menjadi salah satu persyaratan untuk mendapatkan Izin Edar sebagai bukti pemenuhan regulasi berbasis standar. Usulan diterbitkannya regulasi tentang Sertifikasi Produk (SNI) Alat Kesehatan dan Alat Kesehatan Diagnostik In Vitro secara wajib oleh Kementerian Kesehatan dengan memperhatikan ketersedian Lembaga Penilaian Kesesuaian seperti Laboratorium Uji Produk Lingkup Alat Kesehatan yang terakreditasi dan Lembaga Sertifikasi Produk (LSPro) Alat Kesehatan yang terakreditasi.
\end{abstract}

Kata kunci. Sertifikasi Produk (SNI), secara wajib, Alat Kesehatan dan Alat Kesehatan Diagnostik In Vitro, Penilaian Kesesuaian, Produsen

\section{Abstract}

The number of manufacturers of medical devices and In Vitro Diagnostic medical devices that already have SNI certificates is currently very limited. The purpose of this paper is to illustrate that Product Certification (SNI) of Medical Devices and In Vitro Diagnostic Medical Devices by mandatory is needed because SNI sertificate as proof that the medical devices have met the standards in accordance with the standards claimed by the producers, especially those related to safety and performance based on the results of accredited laboratory tests as mandated by regulation No. 36 of 2009 concerning Health and regulation No.20 of 2014 concerning Standardization and Conformity Assessment so as to increase market confidence in both domestic and global markets. Product Certification (SNI) of Medical Devices and In Vitro Diagnostic Medical Devices for Domestic is expected to be one of the requirements to Market License (izinedar) as proof of compliance with standards-based regulations. The proposal for the issuance of the regulation on mandatory product certification (SNI) for Medical Devices and In Vitro Diagnostic Medical Devices by ministry of health by taking into account the availability of Conformity Assessment Body such as the Accredited Medical devices and In Vitro Diagnostic Medical Device Product Testing Laboratory and the accredited Medical devices and In Vitro Diagnostic Medical Device Product Certification Body (LSPro).

Key words. Product Certification (SNI), by mandatory, Medical Devices and In Vitro Diagnostic Medical Devices, conformity assessment body, manufacturer

\section{PENDAHULUAN}

Perkembangan ilmu pengetahuan dan teknologi, khususnya bidang kesehatan baik dari aspek klinis pelayanan medis (clinical medicine) maupun teknologi pelayanan kesehatan (Health Care Technology) pada saat ini telah berkembang sedemikian pesat. Perkembangan teknologi kesehatan ini disebut sebagai evolusi dari sistem teknologi pelayanan kesehatan modern (evolution of the modern health care system) yang secara eksplisit menyatakan bahwa evolusi yang terjadi pada sistem pelayanan kesehatan modern yang telah menciptakan alat kesehatan (medical equipment/medical device) yang berteknologi komplek dan canggih dimana bukti pemenuhan standar keselamatan dan kinerja (safety and performance) alat kesehatan tersebut dibuktikan berdasarkan hasil uji oleh laboratorium yang terakreditasi sehingga menghasilkan pelayanan kesehatan yang bermutu tinggi dengan biaya terjangkau untuk keselamatan pasien, pengguna (user) dan lingkungan.

Perkembangan ini diikuti dengan meningkatnya kerjasama di bidang ekonomi antara negara-negara di dunia seperti World Trade Organization (WTO), Asia Pacific Economic Coorporation (APEC) dan Asean Free Trade Area (AFTA). Demikian pula halnya pada pelaksanaan harmonisasi di bidang standar, regulasi, lembaga penilaian kesesuaian (conformity assessment body) dibidang alat kesehatan telah melahirkan ASEAN Medical 
Devices Directive (AMDD) yang menciptakan sistem perdagangan dunia yang semakin terbuka, bebas dan semakin kompetitif.

Selain itu semakin terbukanya pasar dunia sebagai dampak dari globalisasi, khususnya Pasar Bebas ASEAN peran standar menjadi semakin penting dalam memfasilitasi perdagangan barang dan atau/jasa antar negara, baik di tingkat internasional, regional maupun secara bilateral khususnya di sektor alat kesehatan karena alat kesehatan merupakan salah satu dari 12 (duabelas) sektor prioritas yang dipercepat integritasnya di kawasan ASEAN.

Indonesia telah menandatangani kesepakatan dan berperan aktif di beberapa forum internasional antara lain dalam World Trade Organization (WTO), Technical Barriers to Trade (TBT), Sanitary and Phytosanitary (SPS), Asia-Pacific Economic Coorporation (APEC) dan Asean Free Trade Area (AFTA) dan khususnya di sektor alat kesehatanya itu International Medical Devices Regulators Forum (IMDRF),ASEAN Consultative Committee for Standards and Quality-Medical Devices Product Working Group (ACCSQ-MDPWG), dan Asian Harmonization Working Party (AHWP). Penandatanganan kesepakatan dan peran aktitif tersebut di atas menunjukkan bahwa:

Mengakui hak setiap negara untuk menentukan standar nasionalnya masingmasing;

Meletakkan standar, penilaian kesesuaian dan regulasi teknis menjadi faktor yang penting dalam perdagangan internasional; Mengambil langkah-langkah untuk mengharmonisasikan standar nasional dengan standar internasional seperti ISO/IEC karena standar yang harmonis dengan standar internasional dapat sebagai referensi untuk memperlancar transaksi perdagangan antar negara.

Sertifikasi adalah rangkaian kegiatan Penilaian Kesesuaian yang berkaitan dengan pemberian jaminan tertulis bahwa Barang, Jasa, Sistem, Proses atau Personal telah memenuhi Standar dan/atau regulasi

Sertifikasi Produk (SNI) Alat Kesehatan dan Alat Kesehatan Diagnostik In Vitro secara wajib sangat dibutuhkan karena sampai saat ini jumlah Produsen Alat Kesehatan dan Alat Kesehatan Diagnostik In Vitro yang telah memiliki sertifikat SNI sangat terbatas.

Sertifikat SNI Alat Kesehatan dan Alat Kesehatan Diagnostik In Vitro sebagai bukti bahwa alat kesehatan tersebut telah memenuhi standar sesuai dengan standar yang diklaim oleh produsen khususnya yang terkait dengan keselamatan dan kinerja berdasarkan hasil uji laboratorium yang terakreditasi seperti yang diamanatkan oleh Undang-Undang No.36 Tahun 2009 Tentang Kesehatan dan Undang-Undang No.20 Tahun 2014 Tentang Standardisasi dan Penilaian Kesesuaian.

Sertifikat Produk (SNI) Alat Kesehatan dan Alat Kesehatan Diagnostik In Vitro diharapkan menjadi salah satu persyaratan untuk mendapatkan izin edar sebagai bukti pemenuhan Regulasi Berbasis Standar.
Sertifikasi Produk (SNI) Alat Kesehatan dan Alat Kesehatan Diagnostik In Vitro berbeda dengan sertifikasi ISO 13485. Sertfikasi ISO 13485 bukan Sertifikasi Produk (SNI) Alat Kesehatan dan Alat Kesehatan Diagnostik In Vitro (ISO 13485 is not a product certification standard) karena tidak secara langsung terkait dengan spesifikasi produk alat kesehatan yang diproduksi meskipun audit yang dilakukan berdasarkan ISO 13485 mencakup pemeriksaan desain dan pengembangan produk. Sertifikasi ISO 13485 membuktikan bahwa proses desain dan pembuatan alat kesehatan telah sesuai untuk menghasilkan keselamatan dan kinerja produk secara konsisten. Sertifikat ISO 13485 adalah suatu pengakuan terhadap sistem manajemen mutu pabrik alat kesehatan yang telah mampu menghasilkan alat kesehatan dan layanan (service) terkait yang secara konsisten memenuhi persyaratan konsumen dan persyaratan regulasi alat kesehatan.

Menurut Asean Medical Directives (AMDD 2015) Alat Kesehatan adalah Alat Kesehatan adalah instrumen, aparatus, mesin, perkakas, dan/atau implan, reagen in vitro dan kalibrator, perangkat lunak, bahan atau material yang digunakan tunggal atau kombinasi, untuk mencegah, mendiagnosis, menyembuhkan, dan meringankan penyakit, merawat orang sakit, memulihkan kesehatan pada manusia dan/atau membentuk struktur dan memperbaiki fungsi tubuh, menghalangi pembuahan, desinfeksi alat kesehatan, dan pengujian in vitro terhadap spesimen dari tubuh manusia, dan dapat mengandung obat yang tidak mencapai kerja utama pada tubuh manusia melalui proses farmakologi, imunologi atau metabolisme untuk dapat membantu fungsi/kinerja yang diinginkan.

Dan Alat Kesehatan Diagnostik In Vitro adalah setiap reagen, produk reagen, kalibrator, material kontrol, kit, instrumen, aparatus, peralatan atau sistem, baik digunakan sendiri atau dikombinasikan dengan reagen lainnya, produk reagen, kalibrator, material kontrol, kit, instrumen, aparatus, peralatan atau sistem yang diharapkan oleh pemilik produknya untuk digunakan secara in vitro untuk pemeriksaan dari setiap spesimen, termasuk darah atau donor jaringan yang berasal dari tubuh manusia, semata-mata atau pada dasarnya untuk tujuan memberikan informasi dengan memperhatikan keadaan fisiologis atau patologis atau kelainan bawaan, untuk menentukan keamanan dan kesesuaian setiap darah atau donor jaringan dengan penerima yang potensial,atau untuk memantau ukuran terapi dan mewadahi specimen.

World Health Organization (WHO) memperkirakan saat ini terdapat 2 (dua) juta jenis alat kesehatan dan alat kesehatan diagnostik in vitro yang berbeda di pasar global dan dikategorikan kedalam lebih dari 22.000 kelompok alat kesehatan generik oleh The Global Medical Device Nomenclature (GMDN) dan setiap alat kesehatan tersebut pasti mengacu atau berbasis standar. Standar alat kesehatan tersebut diatas di kelompokkan menjadi tiga kategori besar yaitu: 
I. Basic standards (horizontal standards), yang mencakup konsep fundamental, prinsip dan persyaratan yang dapat diterapakan untuk sebagian besar produk alat kesehatan dan/atau proses, contoh.

a. Quality Management System (ISO 13485:2016),

b. Risk Management System (14971:2007),

c. Clinical investigation (ISO 14155:2011)

II. Group standards (semi-horizontal standards), yang mencakup aspek yang dapat diterapkan untuk kelompok (family) dari produk alkes yang serupa (similar) dan/atau proses yang mengacu kepada basic standars, contoh.

a. Sterility (SNI ISO 11135-1:2014),

b. Electrical safety (IEC 60601 series)

c. Biocompatibility (ISO 10993 series)

III. Product standards (vertical standards), yang mencakup aspek keselamatan dan kinerja dari setiap produk alkes dan/atau proses. contoh.

a. Baby incubator: (SNI IEC 60601-219:2014)

b. Alat suntik sekali pakai (disposable syringe) SNI 16-2608:1992

c. Implan bedah no aktif - Implan pengganti sendi - Persyaratan khusus (SNI ISO 21534: 2011)

d. Sistem uji diagnostik in vitro Persyaratan untuk sistem pemantauan gula darah yang dapat melakukan pengujian sendiri dalam pengelolaan diabetes Meletus (SNI ISO 15197:2009).

Kementerian Kesehatan sampai saat ini telah memiliki sekitar $220 \mathrm{SNI}$ alat kesehatanyang terdiri dari alat kesehatan elektromedik, nonelektromedik, alat kesehatan in vitro diagnostic dan alat kesehatan berbasis IPTEK nuklir. SNI alat kesehatan tersebut diatas telah harmonis dengan standar internasional karena merupakan hasil adopsi identikdaristandar internasional seperti International Organization for Standardization (ISO), International Electrotechnical Commission (IEC).

Penelitian ini bertujuan untuk, (1) Mengingatkan kepada Pemangku Kepentingan (stakeholder) di bidang kesehatan bahwa saat ini dibutuhkan Sertifikat Produk (SNI) Alat kesehatan dan Alat Kesehatan Diagnostik In Vitro sebagai bukti alat kesehatan tersebut telah memenuhi standar seperti yang diklaim oleh produsen, (2) Usulan diterbitkannya Regulasi tentang Sertifikasi Produk (SN) Alat kesehatan dan Alat Kesehatan Diagnostik In Vitro secara wajib oleh Kementerian Kesehatan.

\section{TINJAUAN PUSTAKA}

Kepatuhan Teknologi dan Produk teknologi Kesehatan terhadap metode ilmiah diawali dengan menggunakan prinsip-prinsip ilmiah yang telah dibakukan dimulai dari konsep dan desain diikuti dengan kesesuaian dengan Standar Hasil Konsensus yang mengharuskan produsen untuk membuktikan efektivitas melalui clinical ivestigation dan bukti empiris, serta kepatuhan terhadap Regulasi. Standar dan Regulasi tersebut mewajibkan keselamatan dan kinerja alat kesehatan tersebut harus dibuktikan melalui pengujian oleh laboratorium yang terakreditasi dan penerapan standar manajemen risiko (ISO 14971) terhadap keseluruhan siklus hidup alat Kesehatan (life cycle of medical devices) yang dimulai dari conception and design sampai dengan disposal. Standar dan Regulasi tersebut juga mewajibkan produsen menerapkan standar sistem manajemen mutu alat kesehatan (ISO 13485) yang memastikan setiap perubahan substantif pada desain, bahan, pembuatan, atau fungsi produk didukung oleh bukti klinis atau empiris yang sama. Dengan kata lain, kepercayaan pada Teknologi dan Produk Teknologi Kesehatan dibangun bukan dengan hanya membuktikan pemahaman dan kemampuan, tetapi dengan memvalidasi bahwa teknologi tersebut menghasilkan keluaran yang andal dan dapat diprediksi.

Sebagian besar standar pada dasarnya adalah bersifat sukarela. Walaupun demikian suatu standar dapat diwajibkan oleh perusahaan, masyarakat profesi, industri, atau pemerintah. Standar dapat disebut "regulasi" ketika standar itu diwajibkan. Ketika satu standar diwajibkan oleh pemerintah maka standar tersebut menjadi aturan yang wajib secara hukum berdasarkan regulasi atau undang-undang yang ditetapkan oleh pemerintah (most standards are voluntary. However, a standard may be mandated by a company, a professional society, an industry, or a government. A standard may be called a "regulation" when it is mandatory. When a standard is mandated by a government, it normally becomes legally obligatory based on regulations or a law established by the government).

Amanat Undang-Undang Nomor 36 Tahun 2009 tentang Kesehatan Pasal 42 Ayat 3 menyebutkan sebagai berikut "Teknologi dan Produk Teknologi Kesehatan harus memenuhi standar yang ditetapkan dalam peraturan perundang-undangan"

Amanat Undang-Undang Nomor 20 Tahun 2014 tentang Standardisasi dan Penilaian Kesesuaian menyebutkan sebagai berikut.

- Pasal 20 Ayat 3

"Penerapan Standar Nasional Indonesia (SNI) baik secara sukarela maupun diberlakukan secara wajib harus dibuktikan melalui pemilikan sertifikat dan/atau pembubuhan tanda SNI dan/atau tanda kesesuaian".

- Pasal 24

"Dalam hal berkaitan dengan kepentingan keselamatan, keamanan, kesehatan, atau pelestarian fungsi lingkungan hidup, kementerian/lembaga pemerintah nonkementerian berwenang menetapkan pemberlakuan SNI secara wajib dengan Peraturan Menteri atau Peraturan Kepala Lembaga Pemerintah Nonkementerian". 
Instruksi Presiden Nomor 6 Tahun 2016 tentang percepatan Pengembangan Industri Farmasi dan Alat Kesehatan mengamanatkan "Kementerian dan Lembaga diinstruksikan untuk mendorong pelaku usaha meningkatkan kepatuhan terhadap regulasi dan standar dalam rangka menjamin keamanan, mutu dan manfaat serta peningkatan daya saing industri farmasi dan alat kesehatan".

Instruksi Presiden tersebut diatas melahirkan Permenkes Nomor 17 Tahun 2017 Tentang Rencana Aksi Pengembangan Industri Farmasi dan Alat Kesehatan halaman 84 kolom 3 yang mengamanatkan "Berdirinya laboratorium uji produk dan lembaga sertifikasi produk (LSPro) ruang lingkup alat kesehatan yang terakreditasi dalam rangka sertifikasi alat kesehatan produksi dalam negeri ".

Mengacu kepada Undang-Undang Republik Indonesia Nomor 36 Tahun 2009 Tentang Kesehatan tersebut diatas Kementerian Kesehatan RI mengeluarkan beberapa keputusan tentang alat kesehatan yang merupakan pengganti dari Permenkes 1184/Menkes/Per/X/2004 tentang Pengamanan Alat Kesehatan dan Perbekalan Kesehatan Rumah Tangga sebagai antara lain sebagai berikut.

1. Peraturan Menteri Kesehatan Republik Indonesia Nomor 26 tentang Pelayanan Perizinan Terintegrasi Secara Elektronik Perizinan Sektor Kesehatan.

2. Peraturan Menteri Kesehatan Republik Indonesia Nomor 20 Tahun 2017 Tentang
Cara Pembuatan Alat Kesehatan dan Perbekalan Kesehatan Rumah Tangga

3. Peraturan Menteri Kesehatan Republik Indonesia Nomor 62 Tahun 2017 Tentang Izin Edar Alat Kesehatan, Alat Kesehatan Diagnostik In Vitro dan Perbekalan Kesehatan Rumah Tangga.

4. Peraturan Menteri Kesehatan No.54 Tahun 2015 tentang Pengujian dan kalibrasi Alat Kesehatan sebagai pengganti Peraturan Menteri Kesehatan No.363/Menkes/PER/1998 tentang Pengujian dan kalibrasi peralatan kesehatan pada Sarana pelayanan Kesehatan.

5. Peraturan Menteri Kesehatan Republik Indonesia Nomor 04 Tahun 2014 Tentang Cara Distribusi Alat Kesehatan, yang Baik

6. Peraturan Menteri Kesehatan Republik Indonesia 1189/Menkes/Per/VIII/2010 Tentang Produksi Alat Kesehatan dan Perbekalan Kesehatan Rumah Tangga.

7. Peraturan Menteri Kesehatan Republik Indonesia 1191/Menkes/Per/VIII/2010 Tentang Penyalur Alat Kesehatan.

8. Peraturan Pemerintah Nomor 72 Tahun 1998, tentang Pengamanan Sediaan Farmasi dan Alat Kesehatan ( Lembaran Negara RI Tahun 1998 Nomor 138, Tambahan Lembaran Negara RI Tahun 1998 Nomor 3781).

\section{METODE PENELITIAN}

Metode Penelitian yang digunakan adalah Studi Pustaka dengan kerangka konsep penilitian sebagai berikut.

\section{Kerangka konsep}

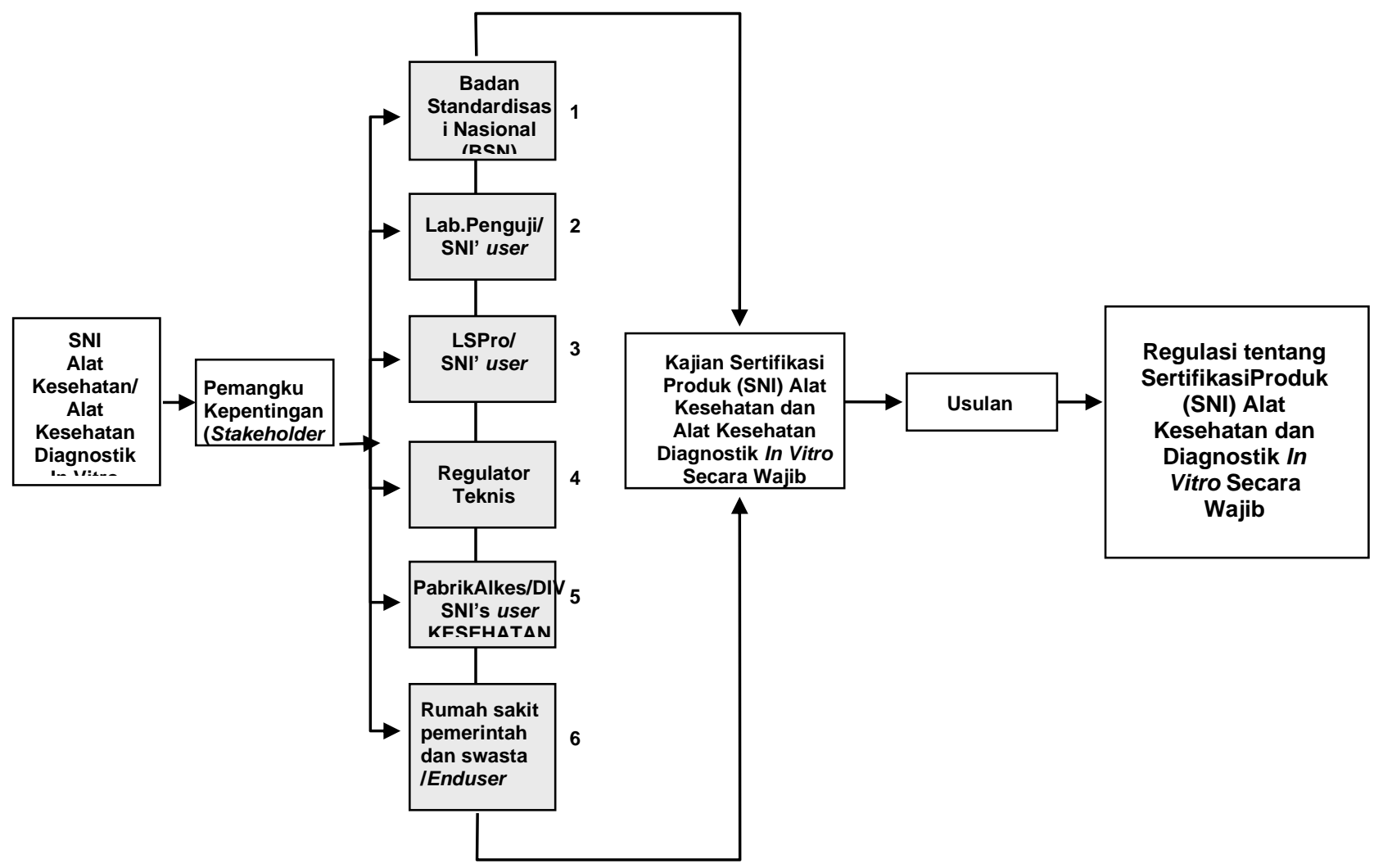


Kerangka konsep tersebut diatas dapat dijelaskan sebagai berikut.

1. Berdasarkan Undang-Undang No.36 Tahun 2009 Tentang Kesehatan dan UndangUndang No.20 Tahun 2014 Tentang Standardisasi dan Penilaian Kesesuaian Kementerian Kesehatan dapat mengadopsi SNI/Persyaratan Teknis alat kesehatan menjadi regulasi tentang SertifikasiProduk (SNI) Alat Kesehatan dan Alat Kesehatan Diagnostik In Vitro Secara Wajib karena terkait Kesehatan.

2. Regulasi tersebut diatas melibatkan Pemangku Kepentingan (stakeholder) seperti Badan Standardisasi Nasional (BSN), Laboratorium Penguji, Lembaga Sertifikasi Produk, Regulator Teknis, Pabrik Alat Kesehatan, Rumah Sakit Pemerintah/swasta (end user)

3. Dibutuhkan kajian untuk Sertifikasi Produk (SNI) Alat Kesehatan dan Alat Kesehatan Diagnostik In Vitro Produksi Secara wajib yang melibatkan Pemangku Kepentingan (stakeholder) tersebut diatas.

4. Hasil kajian ini akan berupa usulan Regulasi tentang Sertifikasi Produk (SNI) Alat Kesehatan dan Alat Kesehatan Diagnostik In Vitro Produksi Secara Wajib kepada Kementerian Kesehatan.

\section{HASIL DAN PEMBAHASAN}

Sertifikasi Produk (SNI) Alat Kesehatan dan Alat Kesehatan Diagnostik In Vitro Secara Wajib sangat dibutuhkan sebagai bukti alat kesehatan tersebut telah memenuhi standar sesuai dengan yang diklaim oleh produsen khususnya yang terkait dengan keselamatan dan kinerja seperti yang diamanatkan oleh Undang-Undang No.36 Tahun 2009 Tentang Kesehatan dan UndangUndang No.20 Tahun 2014 Tentang Standardisasi dan Penilaian Kesesuaian berdasarkan hasil uji laboragtorium yang terakreditasi sehingga meningkatkan kepercayaan pasar baik di dalam negeri maupun pasar global. Sertifikat Produk (SNI) Alat Kesehatan dan Alat Kesehatan Diagnostik In Vitro diharapkan menjadi salah satu persyaratan untuk mendapatkan izin edar sebagai bukti pemenuhan Regulasi Berbasis Standar.

Berdasarkan aplikasi registrasi alat kesehatan Kementerian Kesehatan (data tertanggal 08 Agustus 2020) jumlah Produsen Alat kesehatan dan Alat Kesehatan Diagnostik In Vitro Produksi Dalam Negeri ada sekitar 307 Produsen. Dan berdasarkan aplikasi informasi Kementerian Kesehatan prosentasi produk dalam negeri adalah 9,6\% dan jumlah Izin Edar Alat kesehatan dan Alat Kesehatan Diagnostik In Vitro Produksi Dalam Negeri yang telah diterbitkan sampai saat ini 11.619 Izin Edar tetapi sampai saat ini baru ada sekitar tiga Produsen dalam negeri yang telah memiliki sertifikat SNI sedangkan saat ini Sertifikat SNI Alat Kesehatan dan Alat Kesehatan Diagnostik In Vitro produksi dalam negeri sangat dibutuhkan oleh Produsen sebagai bukti alat kesehatan tersebut telah memenuhi standar sesuai dengan yang diklaim oleh Produsen khususnya yang terkait dengan keselamatan dan kinerja dan untuk meningkatkan kepercayaan pasar terhadap alat kesehatan dan alat kesehatan diagnostik in vitro produksi dalam negeri sebagai hasil atau inovasi anak bangsa baik di pasar domostik maupun global khususnya pasar bebas ASEAN.

Sampai saat ini kementerian kesehatan belum mengeluarkan regulasi teknis berbasis standar yang terkait dengan Sertifikasi Produk (SNI) Alat Kesehatan dan Alat Kesehatan Diagnostik In Vitro Secara Wajib dengan kata lain SNI alat kesehatan dan alat kesehatan Diagnostik yang ada dan sedang dirumuskan saat ini penerapannya masih bersifat sukarela sedangkan permintaan sertifikat produk SNI oleh Produsen alat kesehatan dan alat kesehatan Diagnostik in vitro dalam negeri yang telah menerapkan SNI saat ini semangkin meningkat untuk sebagai bukti bahwa alat kesehatan dan alat kesehatan diagnostik yang mereka produksi telah memenuhi standar.

Sertifikasi Produk (SNI) Alat Kesehatan dan Alat Kesehatan Diagnostik In Vitro Secara Wajib dapat memberikan manfaat sebagai berikut:

1. Alat kesehatan dan Alat Kesehatan Diagnostik In Vitro Produksi yang beredar di Indonesia telah memenuhi (comply) dengan standar yang diklaim oleh Produsen dibuktikan dengan sertifikat SNI dan/atau tanda kesesuaian sehingga keselamatan pasien (patient safety), pengguna dan lingkungan dapat terjamin.

2. Mendongkrak berdirinya Lembaga Penilaian Kesesuaian (LPK) sepeti Laboratorium Uji Produk dan Lembaga Sertifikasi Produk (LSpro) ruang lingkup alat Kesehatan dan alat Kesehatan diagnostik in vitro yang terakreditasi

3. Sertifikat SNI menjadi salah satu persyaratan untuk mendapatkan izin edar alat kesehatan.

4. Sertifikat SNI memiliki nilai tambah bagi industri alat kesehatan dalam negeri untuk meningkatkan keberterimaan pasar baik di dalam negeri maupun pasar global khususnya untuk Pasar Bebas ASEAN.

5. Meningkatkan daya saing bangsa di sektor industri alat kesehatan, khususnya untuk menghadapi MEA karena alat kesehatan merupakan salah satu dari 12 (dua belas) sektor prioritas yang dipercepat integritasnya di kawasan ASEAN.

6. Memudahkan proses pengawasan Alat Kesehatan dan Alat Kesehatan Diagnostik In Vitro yang ada di sarana pelayanan kesehatan dan yang beredar di Indonesia.

7. Mengurangi ketergantungan Indonesia terhadap produk Alat Kesehatan dan Alat Kesehatan Diagnostik In Vitro impor (91\%) terutuma untuk alat kesehatan yang berteknologi sederhana dan sedang.

8. Menghindari Indonesia menjadi tempat sampah bagi alat kesehatan yang tidak standar/substandar. 
9. Mencegah terjadinya kejadian yang tidak diinginkan (KTD) pada Alat Kesehatan dan Alat Kesehatan Diagnostik In Vitro.

\section{A. Kriteria Sertifikasi Produk (SNI) Alat Kesehatan dan Alat Kesehatan Diagnostik In Vitro i Secara Wajib}

Kriteria Sertifikasi Produk (SNI) Alat Kesehatan dan Alat Kesehatan Diagnostik In Vitro Secara Wajib sebagai berikut :

1. Alat Kesehatan dan Alat Kesehatan Diagnostik In Vitro diproduksi di Indonesia

2. SNI Alat Kesehatan dan Alat Kesehatan Diagnostik In Vitro sudah ditetapkan.

3. Banyak digunakan di fasilitas pelayanan kesehatan primer dan masyarakat

4. Telah tersedia Lembaga Penilaian Kesesuaian (LPK) seperti:

- Laboratorium Uji Produk yang terakreditasi

- Lembaga Sertifikasi Produk (LSPro) yang terakreditasi
- Lembaga inspeksi

- Lembaga sertifikasi Sistem Manajemen Alat Kesehatan dan Alat Kesehatan Diagnostik In Vitro.

- Lembaga Sertifikasi Personal

\section{B. Alat Kesehatan dan Alat Kesehatan Diagnostik in vitro memenuhi kriteria untuk disertifikasi}

Dari 200 lebih SNI Alat Kesehatan dan Alat Kesehatan Diangnostik In Vitro yang telah ditetapkan oleh BSN, maka Alat Kesehatan dan Alat Kesehatan Diangnostik In Vitro memenuhi kriteria untuk disertifikasi antara lain seperti yang tertera pada Tabel 1 dan Tabel 2. Tabel 1 Memuat daftar Alat Kesehatan dan Alat Kesehatan Diagnostik In Vitro yang lab uji trakreditasi telah tersedia dan Tabel 2 Memuat daftar Alat Kesehatan dan Alat Kesehatan Diagnostik In Vitro yang lab uji trakreditasi belum tersedia

Tabel 1. Daftar Alat Kesehatan dan Alat Kesehatan Diagnostik In Vitro yang lab uji terakreditasi telah tersedia

\begin{tabular}{|c|c|c|}
\hline No & $\begin{array}{c}\text { Nama } \\
\text { Alat Kesehatan }\end{array}$ & Kriteria \\
\hline 1 & Inkubator bayi & $\begin{array}{l}\text { A. Sudah diproduksi di Indonesia } \\
\text { B. SNI nya sudah ditetapkan (SNI IEC 60601-2-19:2014) } \\
\text { C. Banyak digunakan di fasilitas pelayanan kesehatan } \\
\text { D. Laboratorium Uji Terakreditasi Telah tersedia (P2 SMPT } \\
\text { LIPI) }\end{array}$ \\
\hline 2 & $\begin{array}{l}\text { Peralatan elektromedik - Bagian } \\
\text { 2-30: Persyaratan khusus untuk } \\
\text { keselamatan dasar dan kinerja } \\
\text { esensial tensi meter non } \\
\text { invasiveotomatis (IEC 80601-2- } \\
\text { 30:2009, IDT) }\end{array}$ & $\begin{array}{l}\text { A. Sudah diproduksi di Indonesia } \\
\text { B. SNI nya sudah ditetapkan (SNI IEC 80601-2-30:2014) } \\
\text { C. Banyak digunakan di fasilitas pelayanan kesehatan } \\
\text { D. Laboratorium Uji Terakreditasi Telah tersedia (BPFK) }\end{array}$ \\
\hline 3 & Tempat tidur pasien manual & $\begin{array}{l}\text { A. Sudah diproduksi di Indonesia } \\
\text { B. SNI nya sudah ditetapkan (SNI ISO } 22882: 2011) \\
\text { C. Banyak digunakan di fasilitas pelayanan kesehatan } \\
\text { D. Laboratorium Uji Terakreditasi dan LSPro sudah } \\
\text { tersedia }\end{array}$ \\
\hline 4 & Kondom & $\begin{array}{l}\text { A. Sudah diproduksi di Indonesia } \\
\text { B. SNI nya sudah ditetapkan (SNI 16-2723-2003) } \\
\text { C. Banyak digunakan di fasilitas pelayanan kesehatan } \\
\text { D. Laboratorium Uji TerakreditasiTelah tersedia (BPOM) }\end{array}$ \\
\hline 5 & $\begin{array}{l}\text { Peralatan elektromedik - Bagian } \\
2-52 \text { : Persyaratan khusus } \\
\text { keselamatan dasar dan kinerja } \\
\text { esensial tempat tidur pasien } \\
\text { (IEC 60601-2-52:2009, IDT) }\end{array}$ & $\begin{array}{l}\text { A. Sudah diproduksi di Indonesia } \\
\text { B. SNI nya sudah ditetapkan SNI IEC 60601-2-52:2014) } \\
\text { C. Banyak beredar/digunakan masyarakat } \\
\text { D. Laboratorium Uji Terakreditasi dan LSPro sudah } \\
\text { tersedia }\end{array}$ \\
\hline
\end{tabular}

Tabel 2 Daftar Alat Kesehatan dan Alat Kesehatan Diagnostik In Vitro yang lab uji terakreditasi belum tersedia

\begin{tabular}{lll}
\hline No & Nama Alat Kesehatan & \multicolumn{2}{c}{ Kriteria } \\
\hline 1 & Masker Medis & A. Sudah diproduksi di Indonesia \\
& B. SNI nya sudah ditetapkan (SNI 8488:2018 dan SNI \\
& $8489: 2018$ dan yang terbaru SNI EN \\
& $14683: 2019+$ AC:2019 & \\
& C. Banyak digunakan di fasilitas pelayanan kesehatan \\
& D. Laboratorium Uji Terakreditasi belum tersedia
\end{tabular}




\begin{tabular}{|c|c|c|}
\hline No & Nama Alat Kesehatan & Kriteria \\
\hline 2 & $\begin{array}{l}\text { Sarung tangan untuk } \\
\text { pemeriksaan }\end{array}$ & $\begin{array}{l}\text { A. Sudah diproduksi di Indonesia } \\
\text { B. SNI nya sudah ditetapkan (SNI ISO 11193-1 dan 2:2010) } \\
\text { C. Banyak digunakan di fasilitas pelayanan kesehatan } \\
\text { D. Laboratorium Uji Terakreditasi belum tersedia }\end{array}$ \\
\hline 3 & $\begin{array}{l}\text { Sarung tangan untuk bedah } \\
\text { steril }\end{array}$ & $\begin{array}{l}\text { A. Sudah diproduksi di Indonesia } \\
\text { B. SNI nya sudah ditetapkan (SNI ISO } 10282: 2010 \text { ) } \\
\text { C. Banyak digunakan di fasilitas pelayanan kesehatan } \\
\text { D. Laboratorium Uji Terakreditasi belum tersedia }\end{array}$ \\
\hline 4 & $\begin{array}{l}\text { Peralatan elektromedik Bagian } \\
\text { 2-60: Persyaratan khusus untuk } \\
\text { keselamatan dasar dan kinerja } \\
\text { esensial peralatan dental (IEC } \\
\text { 80601-2-60:2012, IDT) }\end{array}$ & $\begin{array}{l}\text { A. Sudah diproduksi di Indonesia } \\
\text { B. SNI nya sudah ditetapkan (SNI IEC 80601-2-60:2014) } \\
\text { C. Banyak beredar/digunakan masyarakat } \\
\text { D. Laboratorium Uji Terakreditasi belum tersedia }\end{array}$ \\
\hline 5 & Lensa kontak & $\begin{array}{l}\text { A. Sudah diproduksi di Indonesia } \\
\text { B. SNI nya sudah ditetapkan (SNI ISO 1978:2010) } \\
\text { C. Banyak beredar/digunakan masyarakat } \\
\text { D. Laboratorium Uji Terakreditasi belum tersedia }\end{array}$ \\
\hline 6 & $\begin{array}{l}\text { Alat suntik sekali pakai } \\
\text { (Disposible syringe) }\end{array}$ & $\begin{array}{l}\text { A. Sudah diproduksi di Indonesia } \\
\text { B. SNI nyasudah ditetapkan (SNI 16-2608:1992) } \\
\text { C. Banyak digunakan di fasilitas pelayanan kesehatan } \\
\text { D. Laboratorium Uji Terakreditasi belum tersedia }\end{array}$ \\
\hline 7 & Pembalut wanita & $\begin{array}{l}\text { A. Sudah diproduksi di Indonesia } \\
\text { B. SNI nya sudah ditetapkan (SNI 16-6363:2000) } \\
\text { C. Banyak digunakan masyarakat } \\
\text { D. Laboratorium Uji Terakreditasi belum tersedia }\end{array}$ \\
\hline 8 & $\begin{array}{l}\text { Sistem uji diagnostik in vitro - } \\
\text { Persyaratan untuk sistem } \\
\text { pemantauan gula darah yang } \\
\text { dapat melakukan pengujian } \\
\text { sendiri dalam pengelolaan } \\
\text { diabetes Meletus }\end{array}$ & $\begin{array}{l}\text { A. Sudah diproduksi di Indonesia } \\
\text { B. SNI nya sudah ditetapkan (SNI ISO 15197:2009) } \\
\text { C. Banyak digunakan masyarakat } \\
\text { D. Laboratorium Uji Terakreditasi belum tersedia }\end{array}$ \\
\hline
\end{tabular}

\section{Tata cara mendapatkan Sertifikat SNI Alat Kesehatan dan alat Kesehatan diagnostik in Vitro}
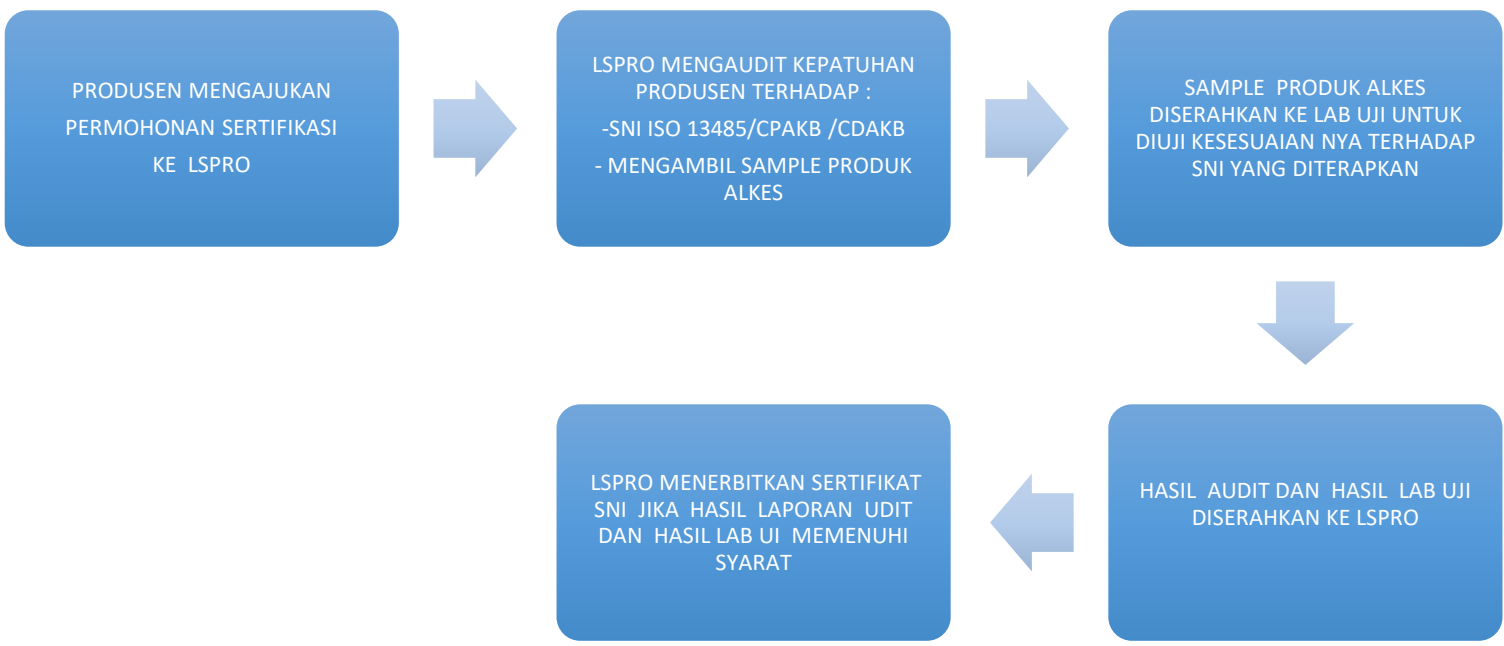

Gambar 2 - Alur tata cara mendapatkan Sertifikat SNI Alat Kesehatan dan Alat kesehatan In Vitro Diagnostik

Alur tata cara mendapatkan Sertifikat SNI Alat Kesehatan tersebut diatas dapat dijelaskan sebagai berikut: Produsen/pabrik Alat Kesehatan dan Alat Kesehatan Diagnostik In Vitro harus meminta penilaian kesesuaian/pensertifikasian alat kesehatan yang diproduksinya ke Lembaga Sertifikasi Produk (LSPro). LSPro akan melakukan Langkah berikut :
1. Mengaudit Produsen Alat Kesehatan dan Alat Kesehatan Diagnostik In Vitro yang mengajukan permohonan sertifikasi SNI produk. LSPro akan melihat apakah Produsen telah menerapklan sistem manajemen mutu untuk produsen alat Kesehatan dan alat Kesehatan diagnostik in vitro yaitu SNI ISO 13485:2016 Alat kesehatan - Sistem Manajemen Mutu - Persyaratan untuk Tujuan 
Regulasi yang dibuktikan dengan sertifikat atau Cara Pembuatan Alat Kesehatan yang Baik (CPAKB) berdasarkan Permenkes No.20 Tahun 2017. Sertifikat ISO 13485 adalah suatu pengakuan terhadap sistem manajemen mutu produsen Alat Kesehatan dan Alat Kesehatan Diagnostik In Vitro yang telah mampu menghasilkan alat kesehatan dan layanan terkait yang secara konsisten memenuhi persyaratan konsumen dan persyaratan regulasi alat kesehatan.

2. LSPro akan mengambil sampel Alat Kesehatan dan Alat Kesehatan Diagnostik In Vitro yang akan disertifikasi dan mengirim sampel alat kesehatan tersebut ke Laboratorium Pengujian yang terakreditasi. Selanjutnya Lab Pengujian akan memberikan laporan hasil uji dan sertifikat hasil uji pada LSPro.

3. Bila berdasarkan audit Produsen tersebut telah memenuhi persyaratan sistem manajemen mutu tersebut diatas dan berdasarkan laporan hasil lab uji proses produksi pada pabri tersebut sudah sesuai dengan persyaratan SNI Produk Alat Kesehatan dan Alat Kesehatan Diagnostik In Vitro yang diterapkannya, maka produk Alat Kesehatan dan Alat Kesehatan Diagnostik In Vitro tersebut akan mendapatkan hak untuk mendapatkan sertifikat SNI dan mencantumkan tanda SNI. Proses ini dikenal sebagai pengajuan Sertifikasi Produk Penggunaan Tanda SNI (SPPT-SNI).

\section{Laboratorium Uji Produk dan Lembaga Sertifikasi Produk (LSPro) terakreditasi.}

Sampai saat ini Kementerian Kesehatan belum memiliki Laboratorium Uji Produk Alat Kesehatan dan Alat Kesehatan Diagnostik In Vitro terakreditasi dan Lembaga Sertifikasi Produk (LSPro) Alat Kesehatan dan Alat Kesehatan Diagnostik In Vitro yang terakreditasi. Laboratorium uji alat kesehatan yang dimiliki kementerian kesehatan sampai saat ini yaitu Balai Pengamanan Fasilitas Kesehatan (BPFK) tetapi bukan dipersiapkan sebagai laboratorium uji produk alat kesehatan tetapi untuk menguji dan mengkalibarasi alat-alat kesehatan yang ada di sarana fasilitas kesehatan (medical device in use).

Semua Laboratorium Penguji, Laboratorium Kalibrasi, Lembaga Sertifikasi Produk (LSPro), Jasa, Sistem, Personil, Proses, dan Lembaga Inspeksi di Indonesia atau yang disebut Lembaga Penilai Kesesuaian/LPK harus diakreditasi oleh Komite Akreditasi Nasional (KAN) dan KAN sendiri sudah dinyatakan memenuhi ISO/IEC 17011, melalui peer evaluasi IAF dan ILAC. KAN sudah menjadi anggota: serta menanda tangani MRA International Laboratory Accreditation Cooperation (ILAC), dan Asia Pacific Accreditation Cooperation (APAC) [cek ke KAN]. Disamping itu KAN juga menjadi aggota dan menandatangani MLA International Accreditation Forum (IAF). Hasil akreditasi KAN diakui oleh negara-negara yang menjadi anggota badan-badan akreditasi dunia tersebut.
Berdasarkan Badan Standardisasi Nasional (BSN) terkait ketersedian LPK untuk memfasilitasi penerapan standar alat kesehatan yang disepakati di ASEAN baru terdapat 1 (satu) Laboratorium Uji Produk Alat Kesehatan yang telah diakreditasi KAN yaitu Laboratorium Pengujian Peralatan Kesehatan P2SMTP - LIPI dengan nomor akreditasi No. LP-505-IDN hanya untuk Lingkup Pengujian Alat Kesehatan Inkubator Bayi dengan acuan Standar SNI IEC 60601-2-19: 2009. Berdasarkan BSN, Lembaga Penilaian Kesesuai (LPK) yang berpotensi untuk dapat ditingkatkan untuk mendukung penerapan standar alat kesehatan di ASEAN adalah BPOM, BPPT, BPFK dan Sucofindo.

Kebutuhan laboratorium uji produk alat kesehatan yang diprioritaskan saat ini serta sarana prasarana yang disyaratkan untuk berdirinya satu laboratorium uji produk Alat Kesehatan meliputi :

1. Peralatan uji dan harga Peralatan uji yang dibutuhkan berdasarkan alat kesehatan yang akan diuji.

2. Parameter yang diuji

3. Standar dan Metode uji yang digunakan.

4. Sumber Daya yang dibutuhkan sesuai dengan kompetensi

5. Luas sarana yang dibutuhkan untuk satu lab uji produk alat Kesehatan dst

Oleh karena itu untuk mendapatkan gambaran kebutuhan laboratorium uji produk alat kesehatan yang diprioritaskan saat ini serta sarana prasarana yang dipersyaratakan maka harus dibangun kerjasama yang sinergi antara Pemangku Kepentingan yang terdiri atas unsur konsumen, pelaku usaha, asosiasi, pakar, cendekiawan, kementerian, lembaga pemerintah non kementerian, dan/atau Pemerintah Daerah (academicy, bussinisman, government and community).

\section{E. Persyaratan mendapatkan izin edar alat kesehatan}

Kementerian Kesehatan telah menetapkan bahwa Alat Kesehatan dan Alat Kesehatan Diagnostik In Vitro yang akan beredar di Indonesia harus memiliki izin edar seperti diatur pada Peraturan Menteri Kesehatan Republik Indonesia Nomor 62 Tahun 2017 Tentang Izin Edar Alat Kesehatan, Alat Kesehatan Diagnostik In Vitro dan Perbekalan Kesehatan Rumah Tangga (Pengganti Permenkes 1190/Menkes/Per/VIII/2010 tentang Izin Edar Alat Kesehatan dan PKRT) dengan persyaratan antara lain (untuk lebih lengkapnya dapat diakses melalui website:www.regalkes.depkes.go.id) sebagi berikut:

- Harus memiliki sertifikat produksi alat kesehatan, dan harus memenuhi sistem manajemen mutu alat kesehatan yaitu SNI ISO 13485 atau Cara Pembuatan Alat Kesehatan yang baik ( CPAKB) diatur di 
Permenkes 1189/Menkes/Per/VIII/2010 tentang Produksi Alat Kesehatan dan PKRT

- Bagi penyalur alat kesehatan harus mempunyai Izin Penyalur Alat Kesehatan (IPAK) dan harus memenuhi sistem manajemn mutu Cara Distribusi Alat Kesehatan yang Baik ( CDAKB) diatur di Permenkes 1191/Menkes/Per/VIII/2010 tentang Penyalur Alat Kesehatan

- Sertifikat analisis produk jadi.

- Test report

- Uji fungsi

- Informasi produk :spesifikasi, contoh gambar

- Kepemilikan merek

\section{KESIMPULAN}

Berdasarkan data hasil kajian tersebut diatas maka dapat disimpulkan sebagai berikut:

- Regulasi tentang Sertifikasi Produk (SNI) Alat Kesehatan dan Alat Kesehatan Diagnostik In Vitro Secara Wajib sangat dibutuhkan oleh Produsen Alat Kesehatan dan Alat Kesehatan Diagnostik In Vitro untuk mensertifikasi produknya sebagai bukti bahwa Alat Kesehatan dan Alat Kesehatan Diagnostik In Vitro tersebut telah memenuhi standar sesuai dengan standar diklaim oleh Produsen khususnya yang terkait dengan keselamatan dan kinerja (safety dan performance).

- Kementerian Kesehatan direkomendasikan segera menerbitkan Regulasi tentang Sertifikasi Produk (SNI) Alat Kesehatan dan Alat Kesehatan Diagnostik In Vitro Produksi Dalam Negeri Secara Wajib yang telah memenuhi kreteria seperti tercantum pada Tabel 1 dan Tabel 2

- Penerapan Regulasi tentang Sertifikas Produk (SNI) Alat Kesehatan dan Alat Kesehatan Diagnostik In Vitro Secara Wajib dengan memperhatikan ketersediaan fasilitas berikut.

a. Laboratorium Uji Produk Lingkup Alat Kesehatan yang terakreditasi

b. Lembaga Sertifkasi Produk Lingkup Alat Kesehatanyang terakreditasi

c. Lembaga inspeksi terakreditasi (17020)

d. Lembaga Sertifikasi Sistem Manajemen Mutu Alat Kesehatan terakreditasi

\section{UCAPAN TERIMA KASIH}

Saya mengucapkan terima kasih kepada Semua pihak yang memberikan waktu dan pengetahuannya sehingga Saya dapat menyelesaiakan karya tulis.

\section{DAFTAR PUSTAKA}

RI, Depkes. (2009). Undang-Undang RI No.36 Tahun 2009 tentang kesehatan. Jakarta: Lembaran Negara RI tahun 2009, (144), Tambahan Lembaran Negara RI (5063);

Indonesia, P.R (2014). Undang-Undang RI Nomor 20 tahun 2014 tentang standardisasi dan penilaian kesesuaian. Jakarta: Tambahan Lembaran Negara RI tahun 2014, (5584)

Peraturan Pemerintah (1998). Peraturan Pemerintah Nomor 72 Tahun 1998, tentang pengamanan sediaan farmasi dan alat kesehatan. Jakarta: Lembaran Negara RI tahun 1998 (138), Tambahan Lembaran Negara RI tahun1998 (3781)

Instruksi Presiden (2016). Instruksi Presiden Nomor 6 tahun 2016 tentang percepatan pengembangan industri farmasi dan alat kesehatan Kemkes (2017).

Kemkes (2017). Peraturan Menteri Kesehatan Republik Indonesia Nomor 17 tahun 2017 tentang rencana aksi pengembangan industri farmasi dan alat kesehatan. Jakarta: Berita Negara RI tahun 2017 (353).

Kemkes (2017). Peraturan Menteri Kesehatan Republik Indonesia Nomor 20 tahun 2017 tentang cara pembuatan alat kesehatan dan perbekalan kesehatan rumah tangga yang baik. Jakarta: Berita Negara RI tahun 2017 (590).

Kemkes (2017). Peraturan Menteri Kesehatan Republik Indonesia Nomor 62 Tahun 2017 tentang izin edar alat kesehatan, alat kesehatan diagnostik in vitro dan perbekalan kesehatan rumah tangga. Jakarta: Berita Negara RI tahun 2018 (82)

Kemkes (2018). Peraturan Menteri Kesehatan Republik Indonesia Nomor 26 tahun 2018 tentang pelayanan perizinan terintegrasi secara elektronik perizinan sektor kesehatan. Jakarta: Berita Negara RI tahun 2018, (887)

Kemkes (2015). Peraturan Menteri Kesehatan No.54 tahun 2015 tentang pengujian dan kalibrasi alat kesehatan sebagai pengganti Peraturan Menteri Kesehatan No.363/Menkes/PER/1998 tentang pengujian dan kalibrasi peralatan kesehatan pada sarana pelayanan kesehatan. Jakarta: Berita Negara RI tahun 2015 (1197)

Kemkes (2014). Peraturan Menteri Kesehatan Republik Indonesia Nomor 04 tahun 2014 tentang cara distribusi alat kesehatan yang Baik. Jakarta: Berita Negara RI tahun 2014 (194)

BSN. (2011). Peraturan Kepala Badan Standardisasi Nasional Nomor 1 tahun 2011 tentang Pedoman Standardisas Nasional Nomor 301 tahun 2011 tentang pedoman pemberlakuan SNI secara wajib.

Kemkes (2010). Peraturan Menteri Kesehatan Republik 
1189/Menkes/Per/VIII/2010 tentang produksi alat kesehatan dan perbekalan kesehatan rumah tangga. Jakarta: Berita Negara RI tahun 2010 (399);

Kemkes (2010). Peraturan Menteri Kesehatan Republik Indonesia 1191/Menkes/Per/VIII/2010 tentang penyalur alat kesehatan. Jakarta: Berita Negara RI tahun 2010 ( 401)

Ed. Joseph D. Bronzino

Boca Raton: CRC Press LLC. (2000)

Biomedical Engineering HandBook,

CRC Press LLC. (2000). The IAF Initiative for accredited Certification to ISO 13485 Medical Devices

WHO. (2018). WHO Global Model Regulatory Framework for Medical Devices including In Vitro Diagnostic Medical Devices

https://apps.who.int/iris/bitstream/handle/10665/ 255177/9789241512350eng.pdf;jsessionid=1B7282AC743F71E81 7C9CDB00CC900C3? sequence $=1$

Pusat Teknlogi Material (2017).Gunakan Alat Kesehatan yang memenuhi standar (https://www.google.co.id/search?q=gunakan+al at+kesehatan+yang+memenuhi+standar\& espv $=2 \&$ biw $=1366 \& b i h=576 \&$ source $=I n m s$ $\& s a=X \& v e d=0 a h U K E w i D o 66 p x \_X M A h U L t$ o8KHR7fCeUQ_AUIBigA\&dpr $=\overline{1}$ )

Joseph F Dyro. (2004). Clinical Engineering Handbook The Biomedical Engineering Series. Hal 557.

Sabarguna BS \& Resna A. Soerawidjaja. UIPress. (2007). Atlas tentan Metodologi + Manajemen Penelitian, Hal.71

Data investasi dan kapasitas industri alat kesehatan dalam negeri

http://regalkes.kemkes.go.id/index.php/home/file Download/BERITA FILE.pdf/1000768

Aplikasi info alat Kesehatan \& PKRT Kementerian Kesehatan RI

http://infoalkes.kemkes.go.id/

Sistem pengawasan alat Kesehatan dan PKRT http://e-watch.alkes.kemkes.go.id 